\title{
Poorly Defined Property Rights and Tropical Deforestation
}

\author{
Etienne Bienvenu Akono (Corresponding author) \\ Faculty of Economics and Applied Management, University of Douala, Cameroon
}

Tel: 237-7627-7925/237-9849-1225

E-mail: akonosong@yahoo.fr

Received: May 14, 2013 Accepted: July 9, 2013 Published: December 25, 2013

doi:10.5296/jee.v4i2.3693 URL: http://dx.doi.org/10.5296/jee.v4i2.3693

\begin{abstract}
The aim of this paper is to analyze the impact of poorly defined property rights on tropical deforestation due to logging activities. We develop two-period and long term frameworks. The short term model analyzes the impact of non-transferability of logging title on deforestation while the long term one examines the influence of rapid expiration of logging title on this environmental issue. We show that the non-transferability and the rapid expiration of logging contracts worsen tropical deforestation.
\end{abstract}

Keywords: Logging title rapid expiration, Logging title non-transferability, Tropical deforestation 


\section{Introduction}

This paper explores the influence of ill-defined property rights on tropical deforestation due to the logging activities. We set up the short term and long term models. The short period framework analyzes the effect of non-transferability of logging title on deforestation and the long period one studies the impact of the rapid expiration of logging right on this environmental problem. Using the example of the Cameroon logging industry, we show that the non-transferability and the rapid expiration of the sales of standing volume logging concessions worsen the tropical deforestation.

Cameroon has the third largest forest in Africa. The estimation of the standing value of the national stock of commercial timber is approximately US\$ 70 billion (Essama-Nssah \& Gockowski, 2000). In respond to an urge drop of the Government's revenues due to a deep decline in the prices of major exports during the 1980's decade, the Cameroonian government, encouraged by the World Bank, reforms the forest sector in order to develop the logging industry and to curb the decrease of its revenues which were mainly stemmed from the cash crops and oil. The government expects this sector to improve the economic growth, the macroeconomic stability and the employment. Both the government and the financial contributors' expectations for an accelerated exploitation of the sector are great. For instance, the 1996 Country Assistance Strategy of the World Bank plans to double the forest export revenues from 1996 to 2004 in its baseline scenario (Essama-Nssah \& Gockowski, 2000). The 1994 forest law is the most important part of that reform. It defines different types of forests (the permanent forest estate and the non-permanent forest estate) and their respective ownership. It aims to incite the national operators to get interested in investing in the logging industry by having easier access to timber than the foreigner investors. In accordance with the 1994 forest law, the logging activities are regulated by an official accreditation in the logging industry and the acquisition of harvest rights. Two types of logging titles are granted by the government after advertising and competitive acquisition of logging rights process: the sales of standing volumes and the forest exploitation contracts. The sales of standing volumes are small tracts of land (no more than 2,500 ha), granted only to Cameroon nationals through a competitive call for tenders for one year with one renewal possible within both the permanent and the non-permanent forests. The section 60 of the 1994 forest law states that the transfer of sales of standing volume is forbidden. The section 158 of that law indicates that a fine from 8,400 to 28,000 US $\$$ or imprisonment for from one to three years or both such fine and imprisonment shall be imposed on whoever commits a transfer as well as a sale of such rights. The forest exploitation contracts are bigger tracts of forest land covering up to 200,000 ha within the permanent forest, granted to both foreigners and Cameroon nationals through a competitive bidding process for 15 years.

The 1994 forest law has created virtuous conditions to the expansion of forest sector in general and the logging industry in particular. By 1998, 479 logging companies were registered in the Cameroon government forest administration, up from 177 in 1990 and 106 in 1980 (Global Forest Watch [GFW], 2000). This indicates an increasing investment path in the logging industry. These recent years, the logging industry is one of the most important part of the national economy. In 1998 it has generated about 28 percent of all nonpetroleum 
export revenues. The Cameroon's forest sector is now the second largest source of export revenue in the economy after petroleum. In 2003 for example, the forest sector represents $16 \%$ of the national exports earnings (about 380 million US dollars), and about $6 \%$ of GDP (Fometé \& Cerutti, 2008).

The drawback of the expansion of the forest sector is the great concern on the tropical deforestation due mainly to the logging industry. Cameroon has the second highest annual deforestation rate in the Congo Basin, after the Democratic Republic of Congo (Global Forest Watch [GFW], 2000). In the recent years, the logging activities have become one of the major causes of the deforestation in Cameroon. The deforestation rate due to logging is evaluated to be between 12 percent and 41 percent, depending on the estimate of the total forest change (Essama-Nssah \& Gockowski, 2000). The sales of standing volume logging rights, which are short term and not transferable are then poorly defined. Those logging rights might explain this high rate of deforestation due to the logging industry, since the nature and distribution of property rights are critical in determining how the resources are used and conserved (Weibe $\&$ Meinzen-Dick, 1998). When property rights are poorly defined, the exploitation of tropical forests for logging is similar to the exploitation of an open access or common pool resource. That open access or common pool management can lead to the resource overexploitation is well known (Gordon, 1954; Scott, 1955).

The literature on deforestation in Cameroon has mainly focuses on the traditional causes of this environmental concern: agriculture, roads construction, war, climate change, etc. There is not any study which has formally tried to analyze the impact of ill-defined property rights on deforestation. This paper attempts to fulfill this lack. Property rights and deforestation have received the attention of some authors. Mendelsohn (1994), examining the land use choice of squatters subject to low rates of eviction, shows that even the minor flaws in the creation and enforcement of property rights can result in widespread destruction of the forests, since the possibility of eviction motives squatters to use the short term destructive land exploitation methods with lower present values. Culas (2007), focusing on a case study of 14 tropical countries, shows that the improvements in the institution for secure property rights can significantly reduce the rate of wasteful deforestation. In a more general case concerning the renewable resources overexploitation, Costello and Kaffine (2008) study the dynamic harvest incentives faced by a renewable resource harvester with insecure property rights. While much attention of the literature has been to study the link between exclusivity, duration and security of property rights and natural resources overexploitation, much less interest has been focused to the role of transferability of property rights and its impact on the natural resources. Our analysis addresses the impact of the non-transferability of logging titles (sales of standing volume) on deforestation. This paper studies the impact of rapid expiration of the sales of standing volume logging titles on deforestation too.

\section{Model of Rapid Expiration of Logging Title}

In the Cameroon forest administration, the sale of standing volume logging right is granted only for one year renewable once, thus for two years maximum. The owner of such right might have incentives to over-log its concession in a wasteful way, because the investments are very high compare to the short working period of the concession. The rapid expiration of 


\section{Macrothink

logging title might then hearten wasteful deforestation. To formalize the link between the rapid expiration of logging right and the deforestation, let consider a logging firm which has applied and won a sale of standing volume through a competitive call for tenders. Let suppose that this logging title is not renewable. Let further suppose that the logging firm decides at time $t$ how much rate of deforestation, denoted by $d_{t}$, he has to realize in order to harvest the timber. Since there is always deforestation in the real world, $\left.d_{t} \in\right] 0,1[$. To simplify, let suppose that the profit function of the logging company depends solely on the deforestation rate and it defines by $v\left(d_{t}\right)=\int_{0}^{T} e^{-\rho t} \log \left[d_{t}\right] d t$, where $\rho$ and $T$ represent respectively the discount rate and the terminal period of the logging contract. The optimization problem of logging firm can be then formally stated as

$$
\begin{gathered}
\left.\max _{d_{t}} x_{0}^{T} e^{-\rho t} \quad 1 \oint d\right] d \\
\text { subject to } \dot{F}=[F(t)]^{\alpha}-F(t) F^{\alpha-1}-d_{t} \\
F(0)=F_{0} \text { and } F(T)=1 .
\end{gathered}
$$

$\dot{F}$ is the natural or biological growth constraint of the remaining stock of forest; $g\left(F_{t}\right)=[F(t)]^{\alpha}-F(t) F^{\alpha-1}$ is the growth function of the remaining tropical forest ; $F(t)$ is the remaining stock of forest; $F$ is the carrying capacity; and $\alpha$ is a constant, with $0 \prec \alpha \prec 1$. Let assume that $\rho \succ \alpha$ meaning that the owner of the sale of standing volume logging right has a very strong preference for the present since this logging concession is a short term non-renewable contract.

The current-value Hamiltonian of the logger's optimal control problem is:

$$
\left.\left.H_{c}=10 £ d_{t}\right]+n\{[F)]^{\alpha}-(F) t^{\alpha-1} F-\right\} \text { with } m \text { the current-value Lagrange }
$$

multiplier.

Under the necessary and sufficient conditions of the maximum principle, it is straightforward to find the following optimal deforestation rate at time $t$ :

$$
d_{t}=d_{0} e^{\left\{\alpha[F()]-\rho-q^{-1}\right\}} \text { where } d_{0} \text { is the deforestation rate at } t=0 .
$$

At the terminal period of the logging title, the optimal deforestation rate path is given by the relation

$$
d_{T}=d_{0} e^{\left(\alpha-\rho-F^{\alpha-1}\right) T}
$$


Deriving this optimal deforestation rate path by the terminal period of the contract yields:

$$
\frac{\partial d_{T}}{\partial T}=-d_{0}\left(F^{\alpha-1}+\rho-\alpha\right) e^{\left(\alpha-\rho-F^{\alpha-1}\right) T}
$$

Since the logger has a very strong preference for the present, $\frac{\partial d_{T}}{\partial T} \prec 0$. This relation means that the short working life of the logging contract (i.e. the rapid expiration of the logging title) exacerbates the deforestation. Because of the rapid expiration of the sale of standing volume logging contract which is not renewable, the eviction possibility leads the logging company to choose cheap and destructive harvest method such as clear-cutting ${ }^{1}$ which induces wasteful deforestation. In fact, the logging company cannot plan its production process in the long period due to the short live period of the logging right. In order to recover its huge investment, the logging firm would have strong incentives to use the cheap harvest method which leads to the loss of the forest cover.

\section{Model of Non-Transferability of Logging Title}

This model is inspired from a gains-from-trade perspective model of Besley (1995). The framework used here, examines whether the sales of standing volumes logging titles, which are non transferable and non saleable, enhance deforestation. Let suppose that a national logger has won a sale of standing volume and decides to sell it to a foreign company in a black market since the transfer and the sale of standing volume are forbidden by the 1994 forest law. The desire to trade is created by the lack of financial credits for national logger who cannot log itself or by the opportunities for foreign company to buy a sale of standing volume which is cheaper and less enforceable than a forest exploitation contract. Let consider that the national and the foreign logging companies bargain to establish the price at which any exchange (trade) takes place.

In the first period, the national logger applies and wins a sale of standing volume. At the beginning of period two, the national logging firm decides to sell it to a foreign company which will use it to harvest the timber. Let assume that there is a trading cost that depends on the foreign company's deforestation rate; an infinite cost is like deforesting on the entire estate allowed by the sale of standing volume. More generally, because the foreign company enjoys advanced harvesting technology and then needs less deforestation to harvest the timber, the foreign firm's less deforestation rate makes it less costly to organize a trade.

To simplify, the return to logging activity is made a linear function of the logging right, and the national logging firm's marginal product of capital if he continues to use the sale of standing volume is denoted by $\theta$. At period 1 , the marginal product is distributed on $[\underline{\theta}, \bar{\theta}]$ with the probability density function $f(\theta)$. The outside valuation is indicated by $\omega$ and is

\footnotetext{
1 The clear-cutting method takes away all trees from an estate in a single cutting. According to the logging firms, the clear-cutting technique increases timber production per hectare by using less skill and planning than other harvesting method (Miller, 2004).
} 
distributed on $[\underline{\omega}, \bar{\omega}]$ with the probability density function $\mathrm{g}(\omega)$. It is the marginal product of capital if the logging title is sold to the foreign logging firm. To simplify, let assume that the valuations are independently distributed. To introduce the importance of deforestation, let suppose that there is a cost of trade function, denoted $\mu\left(d_{t+1}\right) R_{t}$, which is increasing in $d_{t+1}$. $R_{t}$ is the logging right and $d_{t+1}$ represents the deforestation rate made by the foreign logger while harvesting the timber. We assume that a decrease in $R_{t}$ means poorly defined right. A full-information Nash bargain, with a status quo of no trade, is supposed to determine the saleable price. Thus, if the logging right sold in period 1 was $R$, then the equilibrium price of that logging title solves

$$
\operatorname{ma}_{p}\lceil p-(\mu+\theta) R](\omega R-)
$$

The solution of that optimization program gives: $p^{*}=\frac{1}{2}[(\theta+\omega+\mu) R]$

Thus, the payoff to the national logging company if it sales its logging right is $\frac{1}{2}[(\theta+\omega-\mu) R]$. To choose whether to sale or no its logging title, the national logging firm compares this price with the return of enjoying the right himself where his payoff is $\theta R$.

The expected return from using $R_{t}$ if the tropical deforestation rate is $d_{t+1}$ is given by

$$
v\left(R_{t}, d_{t+1}\right)=R_{t} E\left\{\max \left\{\frac{1}{2}\left[\theta+\omega-\mu\left(d_{t+1}\right)\right], \theta\right\}\right\}
$$

Where $E\{$.$\} is the expectations operator taken over \theta$ and $\omega$. Differentiating this equation yields the expected marginal product of capital:

$$
\frac{\partial v\left(R_{t}, d_{t+1}\right)}{\partial R_{t}}=\int_{\underline{\omega}}^{\bar{\omega}}\left(\int_{\underline{\theta}}^{\omega-\mu\left(d_{t+1}\right)}\left\{\frac{1}{2}\left[\theta+\omega-\mu\left(d_{t+1}\right)\right]\right\} f(\theta) d \theta+\int_{\omega-\mu\left(d_{t+1}\right)}^{\bar{\theta}} \theta f(\theta) d \theta\right) g(\omega) d \omega
$$

Differentiating this expected marginal product of capital with respect to $d_{t+1}$ yields

$$
\frac{\partial^{2} v\left(R_{t}, d_{t+1}\right)}{\partial R_{t} \partial d_{t+1}}=-\left\{\int_{\underline{\omega}}^{\bar{\omega}} F\left[\omega-\mu\left(d_{t+1}\right)\right] g(\omega) d \omega\right\} \mu^{\prime}\left(d_{t+1}\right) \prec 0
$$


This implies that $\frac{\partial^{2} w\left(R_{t}, d_{t+1}\right)}{\partial R_{t} \partial d_{t+1}}=\frac{\partial^{2} v\left(R_{t}, d_{t+1}\right)}{\partial R_{t} \partial d_{t+1}}-\mu^{\prime}\left(d_{t+1}\right) \prec 0$ since $\mu^{\prime}\left(d_{t+1}\right) \succ 0$.

At the maximum, $\frac{\partial d_{t+1}}{\partial R_{t}}=-\frac{\frac{\partial^{2} w\left(R_{t}, d_{t+1}\right)}{\partial R_{t}^{2}}}{\frac{\partial^{2} w\left(R_{t}, d_{t+1}\right)}{\partial R_{t} \partial d_{t+1}}}$ and $\frac{\partial^{2} w\left(R_{t}, d_{t+1}\right)}{\partial R_{t}^{2}} \prec 0$. The impact of poorly property rights on the deforestation hinges then on the sign of $\frac{\partial^{2} w\left(R_{t}, d_{t+1}\right)}{\partial R_{t} \partial d_{t+1}}$. Given that, as shown above $\frac{\partial^{2} w\left(R_{t}, d_{t+1}\right)}{\partial R_{t} \partial d_{t+1}} \prec 0$, it is then straightforward to see that $\frac{\partial d_{t+1}}{\partial R_{t}} \prec 0$. This relation means that a decrease in $R_{t}$ i.e. the non-transferability of the sale of standing volume contract worsens the tropical deforestation. The foreign logger by purchasing a sale of standing volume title in a black market faces a fine or imprisonment and consequently eviction likelihood from the land if the government forest administration officials are informed about this forbidden transaction. Because of this eviction possibility, the foreign logging company would have strong incentives to deforest more in order to balance its risky investment by using the unsustainable harvest method such as the clear-cutting one which has less present value.

\section{Concluding Remarks}

This essay showed that poorly defined logging rights in the logging industry exacerbate tropical deforestation. Two models were examined. The first model explored the effect of a rapid expiration of logging title on deforestation in a dynamic scheme. In that model, the logging firm enjoys a poorly defined logging right, the sale of standing volume logging title which is short term and non renewable contract. Since harvesting the forest needs great investment, the logging company which is facing the possibility of eviction from the estate allowed by the logging right, will have strong incentives to log in an unsustainable way (clear cutting method) by clearing the forest in a great proportion in order to get return from its investment during the short working life of the harvesting contract.

The second model analyzed the impact of non-transferable logging title on deforestation. The foreign logging firm by buying a sale of standing volume logging contract in a black market faces a fine or imprisonment and so lives then with the probability that he would be evicted from the land since the transfer or the sale of the sale of standing volume is forbidden by the 1994 forest law. The foreign logging company would then have strong motivations to over $\log$ and then to deforest more in order to compensate its risky investment.

To curb the deforestation due to poorly defined property rights, the government should only grant well defined logging rights. The sales of standing volumes logging concessions should 
then be granted for a long period, for example for more than one decade, and transferable logging titles such that interested parties can exchange them in a formal market. The government should facilitate the organization of such market where loggers can sell or buy those contracts. Those measures would have the advantage to incite the logging operators to harvest in a sustainable way.

This study is still somewhat admittedly imperfect. We analyze only the theoretical approach of the effect of poorly defined property rights on tropical deforestation. An empirical approach could be an interesting exercise. Furthermore, we study separately the impact of rapid expiration and non-transferability of logging title on deforestation. An exciting task could be to analyze whether the two causes of deforestation are independent or not.

\section{Acknowledgements}

The author is grateful to Shihe Fu and two anonymous referees for their helpful and constructive comments on this article.

\section{References}

Besley, T. (1995). Property Rights and Investment Incentives: Theory and Evidence from Ghana. The Journal of Political Economy, 103, 903-937. http://dx.doi.org/10.1086/262008

Costello, C. J., \& Kaffine, D. (2008). Natural resource use with limited-tenure property rights. Journal of Environmental Economics and Management, 55, 20-36. http://dx.doi.org/10.1016/j.jeem.2007.09.001

Culas, J. R. (2007). Deforestation and the environmental Kuznets curve: An institutional $\begin{array}{llll}\text { perspective. } & \text { Ecological } & \text { Economics, } & \text { 429-437. }\end{array}$ http://dx.doi.org/10.1016/j.ecolecon.2006.03.014

Essama-Nssah, B., \& Gockowski, J. J. (2000). Cameroon: Forest Sector Development in a Difficult Political Economy. Washington, DC: World Bank.

Fometé, T., \& Cerutti, P. (2008). Verification in the Forest Sector in Cameroon. VERIFOR.

Global Forest Watch. (2000). An Overview of Logging in Cameroon. Washington, DC: World Resources Institute.

Gordon, H. S. (1954). The theory of a common property resource: the fishery. Journal of Political Economy, 62, 124-142. http://dx.doi.org/10.1086/257497

Mendelsohn, R. (1994). Property Rights and Tropical Deforestation. Oxford Economic Papers, 56, 750-756.

Miller, T. G. J. (2004). Living in the Environment: Principles, Connections, and Solutions. Monterey: Brooks/Cole.

Scott, A. (1955). The fishery: the objectives of sole ownership. Journal of Political Economy, 63, 116-124. http://dx.doi.org/10.1086/257653

Wiebe, K. D., \& Meinzen-Dick, R. (1998). Property rights as policy tools for sustainable development. Land Use Policy, 15, 203-215. 